\title{
WIKIQUESTS, MICROBLOGGING, AND \\ PERSONAL RESPONSE SYSTEMS IN THE HISTORY CLASSROOM
}

\author{
Robert W. Maloy \\ University of Massachusetts Amherst
}

Jeremy Greene

Chelmsford High School, Chelmsford, Massachusetts

\author{
Allison Malinowski \\ Williston Northampton School, Northampton, Massachusetts \\ Joseph Emery \\ Bellows Free Academy, Fairfax, Vermont \\ Kate Curtin \\ Norwood High School, Norwood, Massachusetts
}

Today's middle and high school students have never known a world without computers, the internet, smartphones, text messaging, and other digital technologies. ${ }^{1}$ Social media is central to their lives-95 percent of twelve to seventeen-year-olds are online and eighty percent use Facebook or Twitter for interactive communication and personal learning. ${ }^{2}$ When asked, students say that they want more technology-based learning opportunities at school. In one cross-national history learning study, high school students in the United States and Turkey said they could perform better academically if teachers utilized technological materials more often for classroom activities. $^{3}$

${ }^{1}$ Project Tomorrow, Mapping a Personalized Learning Journey-K-12 Students and Parents Connect the Dots with Digital Learning (April 2012), http://www.tomorrow.org/speakup/pdfs/SU11 PersonalizedLeaming_Students.pdf; Tamar Lewin, "If Your Kids Are Awake, They're Probably Online," New York Times, January 20, 2010, http://www.nytimes.com/2010/01/20/education/20wired.html? $\mathrm{r}=0$.

\footnotetext{
${ }^{2}$ Amanda Lenhart, Mary Madden, Aaron Smith, Kristin Purcell, Kathryn Zickuhr, and Lee Rainie, "Teens' Kindness and Cruelty on Social Network Sites: How American Teens Navigate the New World of "Digital Citizenship,"” Pew Internet \& American Life Project (November 9, 2011), http://pewinternet.org/Reports/2011/Teens-and-social-media.aspx; Project Tomorrow, "From Chalkboards to Tablets: The Emergence of the K-12 Digital Learner" (June 2013), http://tomorrow.org/speakup/SU12_DigitalLearners_StudentReport.html.
}

${ }^{3}$ Ibrahim Turan, "Student Attitudes Toward Technology Enhanced History Education: Comparison Between Turkish and American Students," Journal of Social Studies Education Research 1 (2010), 152-167. 
Many history and social studies teachers, by contrast, have a tenuous relationship with digital technologies as instructional tools. Now four decades into the computer revolution-Microsoft was founded in 1975 and Apple in 1976-history teaching at the high school level continues to feature lectures, fill-in-the-blank worksheets, and multiple-choice exams. ${ }^{4}$ Except for presentation tools such as PowerPoint and Prezi, new technologies are not used regularly in history classrooms as instructional tools.

In this paper we discuss the introduction of three digital technologies-wikis, microblogging, and personal response systems -into high school history classrooms by new teacher candidates from the University of Massachusetts Amherst. In theory, digital technologies could change how history is taught and learned in schools. As two technology educators noted, "there are deep incompatibilities between the demands of new technologies and the traditional classroom." In a technology-infused classroom, lecture-driven approaches give way to more student-centered, collaborative formats for exploring historical topics. In practice, however, new technologies rarely make a smooth transition to successful classroom use.

At one level, the new digital technologies discussed in this paper can be seen as just newer applications of older pedagogical devices and practices: Wikiquests as collaborative research projects, microblogs as student opinion pieces, and personal response systems as quizzes. As history teachers consider the role of new technologies, it is fair to ask: "What can teachers and students do with these tools that cannot be done without them?" We turn to the experiences of new teacher candidates to begin answering this question, recognizing at the outset that instructional change is not built into any computer, software application, or web-based tool. The impacts of technology are realized in how they are used by teachers and students. The experiences reported in this paper are intended to raise issues and offer insights for history teachers and history teacher educators as they integrate digital tools into instructional practice.

\section{Wikis and Wikiquests as Interactive Resources}

A wiki is a website that is edited and maintained by a group of people. This technology has emerged as an increasingly popular way for students and teachers to

${ }^{4}$ Larry Cuban, Hugging the Middle: How Teachers Teach in an Era of Testing and Accountability (New York: Teachers College Press, 2008); Larry Cuban, How Teachers Taught: Constancy and Change in American Classrooms, 1890-1990 (New York: Teachers College Press, 1993).

${ }^{5}$ Allan Collins and Richard Halverson, Rethinking Education in the Age of Technology: The Digital Revolution and Schooling in America (New York: Teachers College Press, 2009), 6. 
create and share history learning. ${ }^{6}$ Wikis enable collaboratively structured learning environments where students and teachers, as well as groups of students themselves, work together on different parts of a topic, discovering concepts and information to share online for all to access. In wiki environments, the teacher's role shifts from expert-in-charge to supporter and facilitator of peer-to-peer interaction, social learning, and technology use. Teachers learn with students just as students learn with teachers.

Wikis encourage students and teachers to work collaboratively in pairs or teams, to learn new processes, make mistakes, and monitor each other's ideas and reasoningimportant ingredients of democratic classrooms. One educator concluded after reviewing recent research on instructional uses of computer-based tools that "wikis are seen as capable of providing more possibilities of open learning environments than many other traditional uses of instructional technology."7

During her student teaching at a local high school, Allison, a history major and master's degree candidate, quickly concluded that teaching history is not the same as telling students information. She noted that to engage students "in learning about topics that 'aren't relevant to my future' as they say, requires me to step away from traditional methods of lecturing and testing if I want to catch and keep student interest and attention." By her own admission, "I taught few classes where students were engaged in a lesson that required traditional note taking of information from a teacher lecture." Providing a range of different activities for classroom learning meant students could never predict a day's learning activities, for as Allison noted:

"Why are we doing this instead of taking notes?" was a question often repeated when I began. Now, used to my attempts at keeping them engaged and interested in the material regardless of the topic, the question I hear is, "What are we doing today?"

For Allison, digital technology became a means for differentiating instruction to involve students in learning. And teaching without a textbook encouraged her to use technology even more than she anticipated when the semester began. Familiar with wikis from her graduate coursework, she developed a "history wikiquest" as part of her unit on the Vietnam War, a required topic under both the Massachusetts and Advanced Placement (AP) United States History curriculum standards.

\footnotetext{
${ }^{6}$ Will Richardson, Blogs, Wikis, Podcasts, and Other Powerful Web Tools for Classrooms (Thousand Oaks, CA: Corwin Press, 2006). See also Audrey Watters, "Why Wikis Still Matter," Edutopia, October 18, 2011, http://www.edutopia.org/blog/wiki-classroom-audrey-watters.
}

${ }^{7}$ Lena Lee, "'A Learning Journey for All”: American Elementary Teachers' Use of Classroom Wikis," Journal of Interactive Online Learning 11 (Winter 2012), 90. 
A history wikiquest is an interactive online learning activity that uses a wikispace as the primary location for multiple sources of historical information. For her wikiquest, Allison used resourcesforhistoryteachers, an open public wiki developed by Robert Maloy at the University of Massachusetts Amherst. ${ }^{8}$ As a multimedia/ multicultural wikispace for teachers and students, created by teachers and students, resourcesforhistoryteachers features different perspectives and a wide range of resources about historical topics listed in the Massachusetts History \& Social Science Curriculum Framework as well as AP standards for U.S. history, world history, and government and politics.

Most of the students were familiar with doing online webquests to learn about a topic. What is different and engaging about a wikiquest is finding all the learning resources accessible from one web space. Allison recalled:

To [my students], wiki means Wikipedia, the only wiki they know. Using that connection, I explained that resourcesforhistoryteachers is also a wiki, a similar concept, but not something that everyone may edit. It may be used by anyone as it has been created for students and teachers everywhere, but materials and resources at the site have been previewed by university faculty and college students.

First, Allison oriented students about how to view, explore, and navigate pages in resourcesforhistoryteachers, with its icons identifying different types of resources. After previewing several wiki pages with students, Allison posted the assignment on Moodle, her high school's online learning management platform. In a folder entitled "Vietnam Wikiquest," students could find two files, one with instructions about how to access the wiki, the other with directions for the assignment.

The directions stated that the students would view different types of materialsaudio, video, primary sources, interviews, photos, and court cases-related to the Vietnam War. The resources were located on the wiki page for the Massachusetts History Standard USII.20 ("Explain the causes, course, and consequences of the Vietnam War and summarize the diplomatic and military policies of Presidents Eisenhower, Kennedy, Johnson, and Nixon") and included the following links:

- Historical Perspectives on the History of Vietnam from Michigan State University's Windows on Asia website.

- Battlefield Vietnam: A Brief History from PBS.

- Transcripts and Audio Recordings from the Presidential Recordings Program at the Miller Center for Public Affairs, University of Virginia. 
- The War in Vietnam: A Story in Photographs from the National Archives with documentary pictures of the war shot by military photographers between 1962 and 1975.

- Vietnam War Causalities by Home of Record from the Virtual Wall at the Vietnam Veterans Memorial.

- President Lyndon B. Johnson's 1968 speech on "Peace in Vietnam and Southeast Asia" in which he announced he would not seek re-election as president.

- Reverend Martin Luther King, Jr.'s 1967 speech, "Beyond Vietnam: A Time to Break the Silence," in which he declared his opposition to the war.

- Clay v. United States, the 1971 Supreme Court case arising from Muhammad Ali's (Cassius Clay) appeal of his 1967 conviction for refusing to report for military induction.

- First-person interview selections from the book Patriots: The Vietnam War Remembered From All Sides by historian Christian Appy, available from Amazon.com.

- "Women: The Unknown Soldiers," an essay posted on a De Anza College website, "The Vietnam Conflict."

- "Women and the Vietnam War" website from the Wellesley College Department of Political Science.

- Teaching the "American War": Looking at the War in Vietnam through Vietnamese Eyes from the website "Primary Source."

- Text of the Vietnamese Declaration of Independence, 1945. ${ }^{9}$

Students were asked to explore two (three for honors credits) different sources from the above list and respond to the following questions:

- Who produced the source? When was it produced? Is the source trustworthy?

- What is the perspective of the source? Is there more than one perspective? What are the main points of the source?

- How does the source relate to class notes, discussions, and readings?

- Using facts, observations, and background knowledge, what is the essential question answered by the source?

Allison observed how the activity was well received by students whose "interest thrived in having choice. By making choices, students were passionate about discussing their sources. They disregarded the option of scanning the easiest or

\footnotetext{
${ }^{9}$ The last three resources on the list were posted on the resourcesforhistoryteachers wiki under World History standards WHII.32 and WHII.38.
} 
quickest sources and instead searched for materials they found historically appealing." Afterwards, students were asked to rate on a scale from 1 (little or no interest) to 5 (interesting and helpful) whether the wikiquest held their attention, was easy to understand, and provided new perspectives on history. All responses were between 3 and 5. One student remarked how "being able to have a choice made the facts stick." Another wrote, "I liked that we could see perspectives from primary sources and from images and text like the casualty list." Allison concluded that choice enabled willing engagement and wide knowledge acquisition among students:

In a "wikiquest" students are encouraged to pursue their own chosen interests. A student response illustrating this is: "I like to do homework online and also being able to listen and watch things instead of only reading." The choices in readings, videos, and audios nurtured a class discussion that included many different perspectives filled with a wide array of facts and data. A typical homework assignment does not fulfill this.

As an interactive learning strategy using digital technology, a history wikiquest is an idea worth pursuing - its learning possibilities cannot be replicated using textbooks or other paper sources. Online, students are able to read an overview of the war, view photographs from the National Archives, peruse oral histories, consult a list of casualties by state, listen to secret White House Oval Office tapes, and watch historic news footage. Students have access to resources that they are less likely to find searching on their own-sites from university faculty and departments, presidential libraries, historical organizations, government agencies, and independent scholars and researchers.

Because of the range and variety of resources, class conversations widen beyond discussions where student research is based on a small number of resources. In Allison's class, one student cited Clay v. United States (1971), explaining the details of why Muhammad Ali was accused of dodging the draft and what choices he was presented with in court. A different student summarized secret correspondence between President Johnson and his advisors as they crafted the Gulf of Tonkin Resolution. A third student, reviewing casualty lists to find that the largest number of draftees came from lower socio-economic status communities (young men who were not enrolled in college), concluded: "I never thought college was for me, but if it gets me out of a war, I should look into it."

Allison's experience raises a fundamental question for history teachers: Can students learn from the wide range of resources found in a wikiquest without first gaining factual background about a topic? In most schools, since students do not have knowledge of historical events, teachers use lectures and textbooks to disperse core information in order to build a foundation for historical study. Given the amount of historical content to teach in schools, is there time enough in class to provide the 
background and engage in the deeper study of primary source and multimedia resources featured in a wikiquest?

Sam Wineburg and colleagues at Stanford University have shown that students do not arrive in middle and high school as empty vessels, completely lacking knowledge or interest about the past. ${ }^{10}$ Students possess broad narratives, what Wineburg calls "collective memory," gleaned from years of family, community, and media experiences (i.e. Hollywood movies). In one study, Wineburg asked high school students and adults aged 45 and over to list the most famous persons in American history, not including Presidents or First Ladies. Both groups named eight of the same persons, suggesting the limited knowledge of shared historical information across generations. ${ }^{11}$ While these collective narratives are incomplete and accompanied by misconceptions and misinformation, they constitute a knowledge base teachers can utilize for historical study.

Viewed in this light, the process of having students read and view different types of online materials does not have to wait until they have heard the lecture, read the textbook, and learned the facts. As a learning experience, a wikiquest can offer new information, opening opportunities for teachers to examine and challenge students' culturally based beliefs about who did what and why in the past. Students who think they know about certain people and events can learn more through an activity such as this. A wikiquest can help to establish a creative balance between gaining knowledge and doing history.

Teaching and learning history in schools is much more than notes, sources, and lectures. At the end of a unit or a year of study, students need to be able to understand events and time periods completely enough to form historically accurate descriptions of what happened, and they need primary and secondary sources to do that. One suggestion is that a wikiquest be used in tandem with an online textbook such as Digital History, an interactive American history website housed at the University of Houston. ${ }^{12}$ Digital History's online materials situate events chronologically while presenting readable summaries of key people, decisions, and consequences-a foundation on which more complete structures of learning can be built.

\footnotetext{
${ }^{10}$ Sam Wineburg, Historical Thinking and Other Unnatural Acts: Charting the Future of Teaching the Past (Philadelphia: Temple University Press, 2001).

"Sam Wineburg and Chauncey Monte-Sano, "“Famous Americans': The Changing Pantheon of American Heroes," The Journal of American History 94 (March 2008), 1186-1202. https:/jah.oxfordjournals.org/content/94/4/1186.full?X
}

${ }^{12}$ Steven Mintz and Sara McNeil, Digital History, http://www.digitalhistory.uh.edu. 


\section{Microblogging Backchannels for Inquiry-Based Learning}

Social media use among young people is changing rapidly as youngsters ages $12-$ 17 move away from Facebook toward photo sharing and microblogging sites. ${ }^{13}$ Instagram and Snapchat are leading sites for sharing pictures and images; Twitter is the most well-known site for posting short messages (or tweets) online. Tweets are not restricted to written text, but can also include pictures, video clips, links, or other forms of digital content. ${ }^{14}$ Increasingly popular in fields like business, marketing, and journalism, image sharing and microblogging are just beginning to be used by teachers.

Joe encountered these changing social media dynamics at the beginning of his high school history teaching internship when he found himself "constantly trying to find a balance between giving students autonomy with learning while at the same time giving guidance and support to help students be successful." He started using Twitter as a way to support learning by reminding students about assignment due dates and providing web links related to class curriculum topics. While this use of Twitter made students more accountable for due dates and upcoming assignments, Joe found it "too passive a tool; I wanted to more directly connect with students by making my Twitter account a desirable destination for students to go to while browsing the Web."

To make his Twitter feed a more visited location, Joe started posting class content online. After showing an in-class Prezi, Joe linked the presentation to his Twitter so students could see it on their computer or mobile device at any time. This allowed students to review class notes digitally before an exam. Joe found this strategy helped students who have difficulty taking notes in class: "Instead of trying to focus on the presentation, taking notes, and my voice, students can concentrate on what I am saying and refer to the presentation later."

Next, Joe began tweeting information pertinent to each day's lesson. If the class was reading an important historical speech or related primary document, he would link to audio or video of that speech or document on Twitter. Having audio or video access outside of class, Joe concluded, "allows students a more complete understanding of the document; how something is said is almost as important as what is said." Another favorite activity was displaying answers to students' questions that he could not answer

\footnotetext{
${ }^{13}$ Shea Bennett, "Tumblr, Facebook, Twitter, Instagram, \& Snapchat-How Teens Use Social Media," Social Times, October 18, 2013, http://www.mediabistro.com/alltwitter/teens-social-media_b50664.

${ }^{14}$ Kay Kyeong-Ju Seo, Using Social Media Effectively in the Classroom: Blogs, Wikis, Twitter and More (New York: Routledge, 2012). See also Educause, "7 Things You Should Know about Microblogging" (July 7, 2009), http://www.educause.edu/library/resources/7-things-you-should-know-aboutmicroblogging; Brian A. McKenzie, "Teaching Twitter: Re-enacting the Paris Commune and the Battle of Stalingrad," The History Teacher 47 (May 2014), 355-372. You can follow historian H.W. Brands as he tweets the history of the United States at Haiku History: The American Saga Seventeen Syllables at a Time, online at https://twitter.com/hwbrands.
} 
immediately during class. "By posting this information on my Twitter account," Joe noted, "I am connecting to the students' passions and allowing them to investigate more fully questions they have."

Yet, while posting Prezi presentations and adding additional content gave Joe's Twitter account more traffic, he thought that it was still a one-sided conversation in which he gave information for students to receive. Moreover, Joe's Twitter posts were mostly limited to those students who had an account. Joe decided that he "wanted a space where students could connect with me and with their peers, and I really liked the idea of only having 140 characters to make students focus their thoughts and be selective about their word choice. His solution was an online backchannel using a website called "TodaysMeet."

A backchannel consists of all the information and conversation in a classroom that is not generated by the teacher. ${ }^{15}$ Every classroom has a backchannel, even if it is not acknowledged officially, where students ask each other questions during class, pass notes, and talk with each other about personal interests. If thoughtfully accessed, the backchannel can give teachers immediate feedback about what students are thinking about academic lessons.

While many teachers either ignore or try to control the backchannel, Joe decided to use this communication process as a way for students to ask questions, share insights, and generate responses to classroom activities. The online backchannel of "TodaysMeet" functioned like a Twitter feed. Students could generate short comments (140 character limit) that would display either on Joe's computer at his desk or on a large screen at the front of the room when he connected his machine to an overhead projector.

Joe used the backchannel in two different ways: "First, during a presentation, the backchannel enabled students to ask clarifying questions, signal me to slow down, or to flag issues with the presentation." Second, everyone could see when "students posted responses to each other based on primary source documents." One example of this second use happened while studying American policy during the Spanish-American Cuban Filipino War. Two dominant ideas were being discussed: 1) The United States was saving Cuba and the Philippines from Spanish colonial oppression, and 2) the United States was removing Spain from its position of colonial dominance in order to take its place. To explore these ideas more fully, Joe asked students to examine excerpts from history textbooks published in the United States, Cuba, Jamaica, Spain,

\footnotetext{
${ }^{15}$ For more background on backchanneling, see Richard Byrne, "Try TodaysMeet for Back-Channel Chat without Distraction," Free Technology for Teachers (December 4, 2009), http://www.freetech4teachers. com/2009/12/todaysmeet-for-back-channel-chat.html\#.UrNAOhxiC7t; Richard Byrne, "A Teacher's Guide to Classroom Backchannels and Informal Assessment Tools," Free Technology for Teachers (January 29, 2013), http://www.freetech4teachers.com/2013/01/a-teachers-guide-to-classroom.html\#. UWit26saeJI.
} 
and the Philippines. ${ }^{16}$ Not knowing which excerpt came from which book, students used the backchannel to discuss where they thought each excerpt came from and why. As Joe observed, "It was fun to see students engaging with the text and one another, challenging opinions and having a dialogue about a primary source."

For Joe, Twitter and "TodaysMeet" in the classroom became exciting methods to engage students while giving them greater autonomy in learning. He saw students continuing their development as engaged, motivated learners when they had opportunities to express ideas using this technology. At the same time, utilizing these microblogging technologies raises issues for history teachers to consider. One is access. While many students and schools have laptops and mobile devices, some do not. Successful implementation of backchannel conversation tools would seem to require that every student have access to a personal device to avoid digital inequality in the classroom.

A second issue is usage and purpose. Will mobile devices be a distraction from the processes of academic learning? Will students accomplish class work more readily with regular access to handheld tools? By employing the use of laptops or phones during class time, everyone in a classroom is entering into a social contract whereby students agree to stay on task and engage in thoughtful learning while teachers agree to make academic activities engrossing, not dull. Guidelines need to be developed with students so they are part of the process of guiding learning with technology. Trying to create and enforce rules about mobile technologies without significant student input and support is not likely to succeed. And parental input is a whole other issue.

Also present are practical questions about how teachers grade and monitor student backchannel activity and online statements. Should teachers use a rubric, a checklist, or have a mandated requirement that everyone post at least once during a class session? Additionally, rules must be agreed upon to prevent inappropriate or offensive statements by students about other students. As microblogging becomes a more widely used communication and instructional technology, everyone - teachers, administrators, parents, and students-must collaboratively establish norms and expectations for its use.

Finally, conversation is needed about the depth of analysis that can be shared using short messages. Learning history requires historical thinking, a process that involves analyzing primary sources, reading multiple accounts of events, understanding historical context, and being able to weigh evidence to support claims about what

\footnotetext{
${ }^{16}$ Dana Lindaman and Kyle Ward, History Lessons: How Textbooks from Around the World Portray U.S. History (New York: The New Press, 2006).
} 
happened. ${ }^{17}$ Students must present and defend their interpretations of events, and to be able to do so requires deliberate study and clear analysis. Short responses such as those on Twitter or "TodaysMeet" might well aid the development of those skills as they help students to formulate viewpoints and express them cogently online. Therein rests an important tradeoff for teachers and students. Microblogging might promote active student investigation into the decisions and choices people made in the past, and that process could create a foundation on which more in-depth historical analysis can be accomplished.

\section{Personal Response Systems for Learning Assessments}

Personal Response Systems (PRS-sometimes known as audience response systems) allow students to answer questions in real-time using handheld digital devices (or clickers) while teachers can share that information with all the members of a class. Once students have submitted answers to various types of forced choice questions (for example, multiple choice, Yes/No, matching, or True/False), the system instantly displays those answers in a graphic or table format. Teachers and students can see immediately if everyone understands a topic under discussion, if additional activities are needed to clarify understanding, or simply where everyone stands on a question or issue under discussion. Popular at the college and university level as a way to engage students in large classes, personal response systems are becoming more widely used in middle and high schools.

For her senior-year Honors Program Capstone Project, Kate decided to explore using a personal response system in teaching history in secondary school classrooms. Earlier that fall, she attended a lecture by Brian Lukoff, a postdoctoral fellow at Harvard, speaking about the different ways that teachers can create interactive learning in classrooms. ${ }^{18}$ Lukoff described ways to use technology-based systems where students respond to teacher questions using personal digital devices (laptops, tablets, iPods, or phones). ${ }^{19}$ The assumption underlying these approaches is that students will be more mentally engaged if they can respond to academic subject matter in self-chosen and interactive ways.

\footnotetext{
${ }^{17}$ Daisy Martin, "What Is Historical Thinking?" National History Education Clearinghouse, January 10 , 2011, http://teachinghistory.org/historical-thinking-intro.
}

${ }^{18}$ Brian Lukoff, "Using Learning Catalytics to Create an Interactive Classroom," STEM Tuesday Talk at the University of Massachusetts Amherst (February 5, 2013).

${ }^{19}$ Emily Hanford, "Rethinking the Way College Students are Taught," American Radio Works (Septernber 2011), http://americanradioworks.publicradio.org/features/tomorrows-college/lectures/ rethinking-teaching.html. 
With Lukoff's ideas as a starting point for encouraging interactive learning, Kate visited a high school history classroom, taking along a portable Insight 360 Personal Response System. She and the teacher of the class decided to use the PRS to review information from a previous night's history homework. Using the assigned reading as a reference, Kate composed twenty multiple-choice questions that highlighted key points, writing the questions in the style of the Advanced Placement United States History exam.

After explaining to students how the homework review would proceed differently than usual, she distributed the PRS clickers and went through the questions with the class, discussing the answers for each question with special attention to the ones that many of the students did not answer correctly. When she finished, she asked students for their evaluation of the response system using a scale from 1 (little or no interest) to 5 (very interesting and helpful). None of the students had used a personal response system in class before this experience.

On the helpfulness and comprehension scales, the students ranked the PRS activity a 4 on the five-point scale. But as Kate read students' comments, she concluded "what was most exciting was that 95 percent of the students said that their attention was held at level 5; the personal response system approach had been more engaging than other reviews they had done."

Students were asked to give written feedback about what they liked and did not like about using the PRS for homework review. Most described the activity as being fun; they liked having a clicker in their hands and they liked pressing buttons to get an immediate response. One student appreciated seeing responses displayed in a bar graph that showed the number of classmates who chose each answer, declaring how "it was exciting to see the number of people who guessed different answers. It made the review more competitive, but it also helped show where the class was confused." Another student cited the anonymity of the clicker responses: "What I liked the most was that no one was being called on specifically."

Some of the students said the font size of the questions was too small, making them hard to read. Others said they found some of the questions too challenging. Yet, overall students found the clickers an engaging way to gather information and discover where they needed to improve their knowledge and enlarge their understanding. One student summarized the viewpoint of the class: "It's pretty cool how we have this technology. I like how answers are confidential but you still get the chance to see the results and notice where you need to improve."

A personal response system in the classroom clearly seems to have the potential to expand lessons beyond the standard lecture and text reading history curriculum. Using a digital tool to respond to questions, students appear to be engaged and the learning could be more stimulating than paper-based quizzes. Importantly, by engaging students in evaluating their responses critically, a teacher has the opportunity to observe thinking and reasoning practices and then adjust teaching methods to fit those needs. 
Research from science classrooms further suggests the value of quiz questions as a teaching and learning strategy. ${ }^{20}$ In one study, students who read material and then took a test shortly thereafter retained fifty percent more of the material a week later than students who used two other common learning strategies - either studying the material extensively on their own or drawing diagrams and concept maps about what they had read. ${ }^{21}$ Other researchers at the college level have found that the use of clickers in class produced greater participation and engagement among students, although not necessarily statistically significant improvements in exam scores when compared to those taught using traditional formats. ${ }^{22}$

This research would seem to suggest that there are benefits to history teachers quizzing students regularly in class, both to promote engagement and potentially to improve test performance. In this methodology, personal response systems offer a way to combine repeated content review with engaging digital technologies. Quizzing students regularly does not have to be done in a competitive format or in ways that overemphasize the importance of student performance on these activities. Rather, these assessments can be formative in nature so students could become involved in assessing learning progress.

At the same time, personal response systems raise a contradictory, perhaps paradoxical, question: Will the benefits of quizzing, which seem clear and incontrovertible, lead students and teachers away from extended interpretations of historical sources and historical causality? Earlier, we asked whether wikiquests and microblogging introduce too much open-endedness into the history classroom without sufficient attention to the basic outline of historical chronology. Now, clicker systems and repeated quizzing might go too far the other way, reinforcing an older notion that

\footnotetext{
${ }^{20}$ See also Stuart Singer, "From a Teacher's Perspective: Test, Test, and Then Test Some More," The Principal Difference, National Association of Secondary School Principals (February 9, 2011), http://nasspblogs.org/principaldifference1/2011/02/from-a-teachers-perspective-test-test-and-then-testsome-more/; Karl K. Szpunar, Novall Y. Khan, and Daniel L. Schacter, "Interpolated Memory Tests Reduce Mind Wandering and Improve Learning of Online Lectures," Proceedings of the National Academy of Sciences (February 18, 2013), http://www.pnas.org/content/early/2013/03/27/1221764110. full.pdf + html.
}

${ }^{21}$ Jeffrey D. Karpicke and Janell R. Blunt, "Retrieval Practice Produces More Learning than Elaborative Studying with Concept Mapping," Science 331 (February 2011), 772-775, http://science. sciencemag.org/content/331/6018/772.

${ }^{22}$ Emma D. Bojinova and James N. Oigara, "Teaching and Learning with Clickers: Are Clickers Good for Students?" Interdisciplinary Journal of E-Learning \& Learning Objects 7 (January 2011), 169-184; David S. Fiske, Renea Fiske, and Krystal Lucio, "Does Clicker Technology Improve Student Learning?" Joumal of Technology \& Teacher Education 20, 2 (2012), 113-126; Lorena Blasco-Arcas, Isabel Bull, Blanca Hernandez-Ortega, and F. Javier Sese, "Using Clickers in Class. The Role of Interactivity, Active Collaborative Leaming and Engagement in Learning Performance," Computers \& Education 62 (March 2013), 102-110. 
history involves memorizing names, dates, facts, and places. Finding a balance between these opposing points will be another challenge for history teachers if they continue to integrate digital technologies in the classroom.

\section{Conclusion}

In these classrooms, the use of new digital technologies generated significant changes in teaching methods for teachers and students alike. While history teacher candidates and high school students could be said to be technologically savvy based on prior experiences with computer technologies, none had accessed a wiki previously, done microblogging, or used a personal response system. Teacher candidates and students thus encountered new technologies in novel and unexpected ways, generating questions and gaining insights relevant to all of us involved in history education.

History teacher candidates ventured away from more traditional methods of teaching history they had experienced in their own education. Doing a wikiquest enabled students to research American involvement in Vietnam in ways sharply different from a teacher-based lecture about the topic. Through microblogging, students expressed perspectives and opinions that might otherwise have remained unvoiced by individuals who are reluctant to speak in class. Using a personal response system for topic review, students had the opportunity to analyze answer choices without feeling as though wrong answers would be penalized or criticized.

Familiar with using technology for personal communication and recreation, high school students responded positively to using technology for learning. Their responses affirmed that they were both surprised and pleased that history learning could happen in interesting and interactive ways. Longer-term studies are needed to assess whether new technologies generate substantive improvements in student learning, but the students in these classes were visibly more engaged in thinking about and analyzing historical topics.

As for the potential transformative impact of technology on instructional practice, did these new digital tools make it possible for teachers and students to do learning activities in new ways they could not have done without these technologies? In each case, technology changed the experience for teachers and students. Unlike non-digital forms of collaborative research, wikiquests made high-quality, multimedia online resources instantly available to students. Using a wiki means that teachers and students must learn how to assess the reliability of online resources. Teachers' collection of web-based materials in digital space then allows students to engage in never before possible interactive learning experiences-from building a medieval cathedral to viewing historic documentaries, listening to famous speeches, recreating battles, and engaging in countless other historical explorations.

In a similar way, microblogging and personal response systems change the nature of individual and group discussion. Microblogs activate a backchannel of student thinking by allowing individuals and groups to post their thoughts in real time. 
Personal response systems allow students to respond to both factual recall and openended questions without facing pressure from peers or teachers when speaking aloud in class. These interactions are not possible in face-to-face conversations or small group cooperative learning settings. Technology educator Marc Prensky has characterized this technology-driven change as moving from "doing old things in old ways" to "doing old things in new ways" to "doing new things in new ways."23

At the same time, the use of new technologies does not have to mean abandoning longstanding non-technological teaching practices. Group work, face-to-face discussions, and rethinking one's ideas in response to thoughtfully posed questions can happen alongside wikis, microblogs, and personal response systems. What began to emerge in the classrooms of these three teacher candidates was a blend of interpersonal and technological experiences that point the way toward a more active and engaged history teaching.

Computers, online resources, and other digital tools give teachers exciting new ways to organize historical learning. The challenge is to continually investigate the uses of technology in the classroom, improving what works while recognizing, as one commentator noted at the beginning of education's computer revolution, that "technologies do not change schools in any sense worth talking about. Thoughtful, caring, capable people change schools, sometimes with the help of technology, sometimes not, and sometimes even despite it." ${ }^{24}$ Effective teachers and actively engaged students are the ingredients for successful history education in schools. Finding ways for technology to further that goal is the challenge going forward.

\footnotetext{
${ }^{23}$ Marc Prensky, "Shaping Tech for the Classroom: $21^{\text {st }}$ Century Schools Need $21^{\text {st }}$ Century Technology," Edutopia, April 13, 2014, http://www.edutopia.org/adopt-and-adapt-shaping-tech-for-classroom.

${ }^{24}$ George Brackett, "Technologies Don't Change Schools-Caring, Capable, People Do," in The Digital Classroom: How Technology is Changing the Way We Teach and Learn, ed. David T. Gordon (Cambridge: Harvard Education Press, 2000), 29-30.
} 